\title{
Predictive factors of visual outcome after local resection of choroidal melanoma
}

\author{
Bertil E Damato, James Paul, Wallace S Foulds
}

\begin{abstract}
Local resection of choroidal melanomas is not widely performed so that the indications for this operation have not previously been defined statistically. Univariate and multivariate Cox regression analyses were used to identify the factors influencing visual acuity after $163 \mathrm{com}$ pleted local resections for choroidal melanoma in patients with a preoperative visual acuity of counting fingers or better. The variables included in the analyses were patient age and sex; eye laterality and preoperative visual acuity; location of anterior and posterior tumour margins; tumour location (coronal and sagittal); tumour diameter, thickness, and cell type; ocular decompression by vitrectomy; and adequacy of surgical clearance. The surgical resections were performed using a lamellar scleral flap for eye closure, hypotensive anaesthesia for haemostasis, and, in the later years, ocular decompression by pars plana vitrectomy to improve access. The patients (94 men, 69 women) had a mean age of 50 years. The tumours had a mean diameter of $13.3 \mathrm{~mm}$ and a mean thickness of $7.4 \mathrm{~mm}$, with 38 tumours extending to within 1 disc diameter (DD) of the optic disc, fovea or both (that is, 'posterior tumour extension'). Cox multivariate analysis showed that the most significant preoperative factors for predicting retention of good vision (6/12 or better) were nasal tumour location $(p=0.002)$ and distance of more than $1 \mathrm{DD}$ between the tumour and the optic disc or fovea $(p=0 \cdot 010)$. The most significant predictive risk factor for severe visual loss (hand movements or worse) was posterior tumour extension to within $1 \mathrm{DD}$ of the optic disc and/or fovea $(p=0 \cdot 009)$. One year postoperatively, all 28 patients with nasal tumours not extending to within 1 DD of the optic disc or fovea retained the eye with $57 \%$ having vision of $6 / 12$ or better and $93 \%$ having vision of counting fingers or better. In 68 patients with temporal tumours, $90 \%$ retained the eye at 1 year with preservation of vision of counting fingers or better in $82 \%$ of 56 eyes without posterior tumour extension and in $\mathbf{5 0 \%}$ of 12 eyes with posterior tumour extension. In patients with choroidal melanoma, conservation of the eye and vision can be achieved by local resection, especially if the tumour is located nasally and does not extend close to the disc or fovea.

(Brf Ophthalmol 1993; 77: 616-623)
\end{abstract}

The treatment of choroidal melanomas by enucleation has been augmented by less mutilating forms of therapy such as radiotherapy, ${ }^{1-4}$ photocoagulation, ${ }^{5}$ and local resection ${ }^{6-17}$ which are aimed at conserving vision. At present, the commonest forms of treatment are plaque radiotherapy and charged particle radiotherapy. Local resection of posterior tumours is performed by relatively few surgeons because of the controversial nature and the technical difficulty of the operation. Published series have therefore been too small to allow visual outcome following local resection to be correlated statistically with factors, such as the age and sex of the patient and the size and location of the tumour.

In this study, we evaluated the postoperative vision in 163 patients with choroidal melanoma who were treated by local resection between 1972 and 1991, updating interim results that were reported previously. ${ }^{918}{ }^{19}$ Our objectives were to identify the most important predictive factors for visual outcome after local resection so that the main indications for this operation could be defined.

\section{Patients and methods}

PREOPERATIVE ASSESSMENT

Our methods of preoperative assessment are described elsewhere. ${ }^{20}$ Vision was measured with a Snellen chart, using a spectacle correction if usually worn by the patient, or pinhole aperture. The following data were obtained at the time or by reviewing photographs and records: (i) tumour height and largest and smallest tumour diameters as measured by B scan ultrasonography; (ii) location of anterior and posterior margins of the tumour; and (iii) coronal and sagittal location of the tumour. The tumour was said to have 'posterior tumour extension' if its posterior margin was situated at or within 1 disc diameter (DD) of the disc margin or fovea. The coronal location of the tumour was categorised as 'nasal' if the 'centre of gravity' of the tumour was nasal to a vertical line passing through the fovea.

\section{SURGICAL TECHNIQUE}

From 1970 to mid-1984, all of the surgery was performed by WSF. From mid-1984, BED undertook an increasing share of the surgery, performing the majority of the operations from 1986 onwards and all operations in this series 


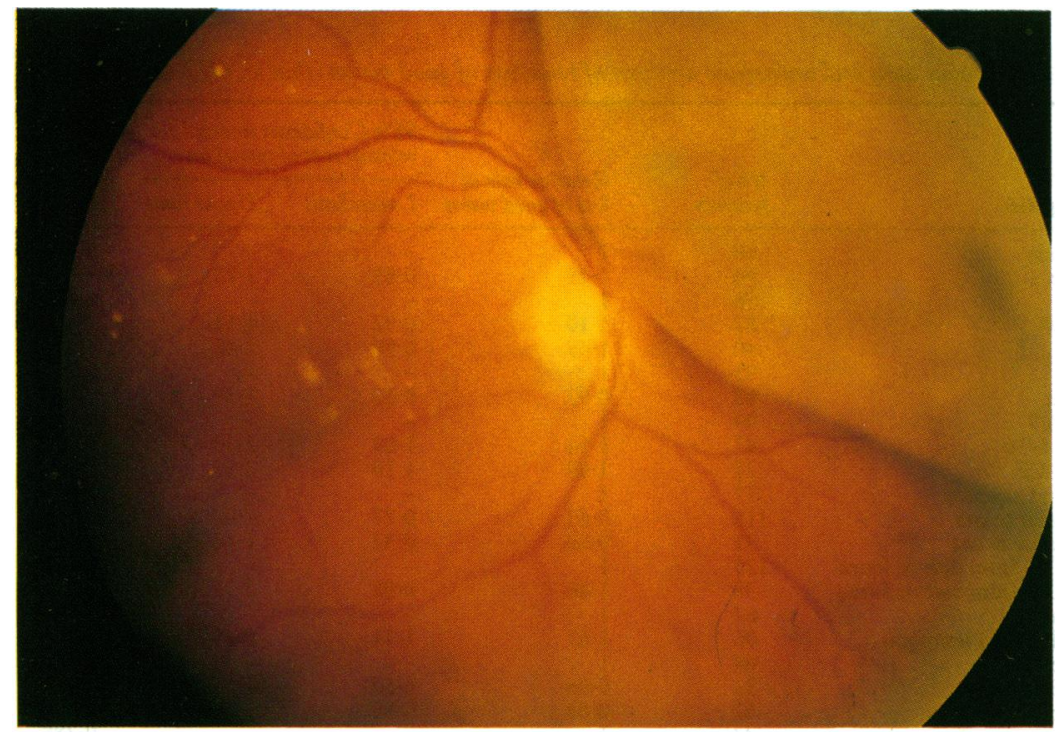

Fig $1 A$

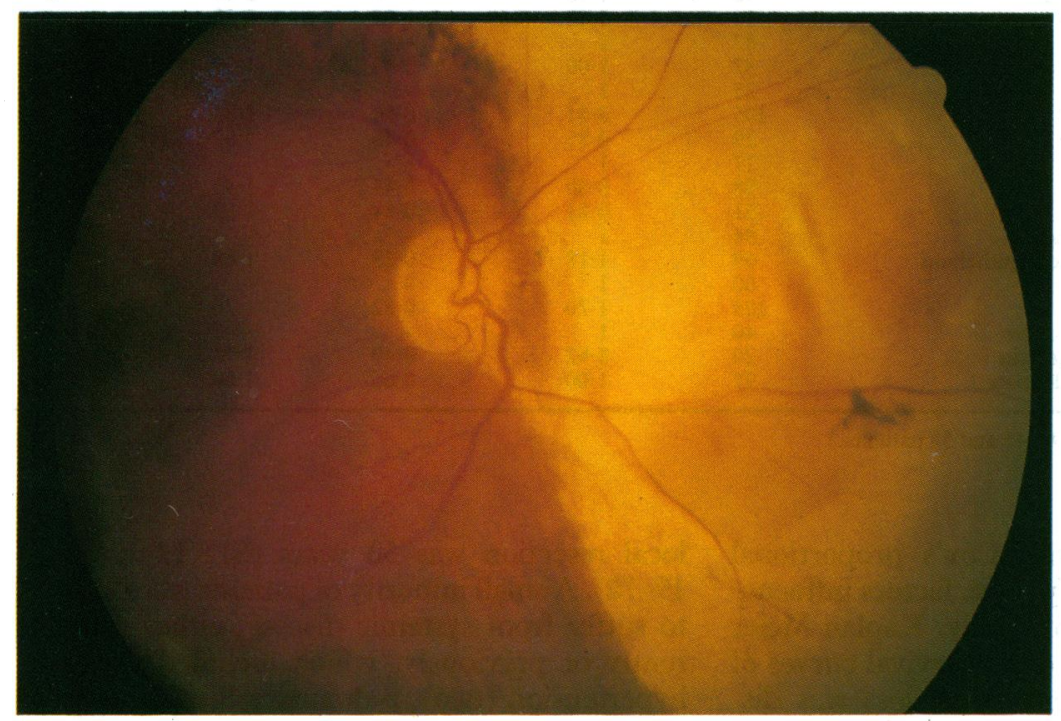

Fig $1 B$

Figure 1 Right fundus of a 72-year-old man $(A)$ preoperatively, showing a superonasal choroidal melanoma of spindle $B$ cell type, with basal dimensions of $14 \mathrm{~mm}$ by $12 \mathrm{~mm}$ and $a$ thickness of $7 \mathrm{~mm}$, and $(B)$ 9 months postoperatively, when the visual acuity was $6 / 9$. after mid-1989. The surgical techniques are described in detail elsewhere ${ }^{20}$ (Fig 1). Briefly, the tumour margins were identified by transpupillary transillumination. A rectangular lamellar scleral flap, hinged posteriorly, was dissected. Since 1986, partial ocular decompression was routinely performed, either before the dissection of the scleral flap by three port vitrectomy (WSF), or after preparation of the flap, via a single sclerotomy and without infusion (BED). The deep sclera and choroid were divided some 3-5 $\mathrm{mm}$ from the marked edge of the tumour. Haemorrhage was minimised by lowering the systolic blood pressure to approximately 40-60 $\mathrm{mm} \mathrm{Hg} .{ }^{21}$ The sclera was closed with interrupted 8-0 nylon sutures. Any small extraocular tumour nodule was excised with a surround of full thickness sclera and the defect in the lamellar flap was closed with a lamellar graft taken from a healthy part of the same eye. External plombage and/or internal tamponade with gas or silicone were used to prevent retinal detachment if a large retinal defect was created. In the later years of the study, photocoagulation was routinely applied to the margins of the surgical coloboma postoperatively to minimise the risk of retinal detachment and to prevent tumour recurrence.
PATHOLOGICAL EXAMINATION

Tumours were categorised as spindle cell, mixed, or epithelioid but the latter two types were considered together for this study because of the small number of purely epithelioid tumours (four). Surgical clearance was considered adequate if normal choroid was present beyond the tumour margin, uncertain if tumour extended close to the excision edge, and inadequate if tumour was present at the resection edge.

\section{PATIENT FOLLOW UP}

After the local resection, patients were reviewed after 1 month, 6 months, and then annually, if possible, unless more frequent visits were indicated due to complications. The following data were recorded: (i) visual acuity, measured with a Snellen chart either unaided, or with current spectacles and pinhole as appropriate; and (ii) ocular and systemic complications and the date of their diagnosis.

\section{STATISTICAL METHODS}

During the 18 months preceding the close of the study or the date of death, follow up data were obtained on $117(97 \%)$ of all the 121 live patients still retaining the operated eye and on 19 out of 22 patients who died during the study. Patients were not excluded from the study because of incomplete follow up or loss of the eye. The data were derived from examinations performed by one of the clinical authors (BED or WSF) or by the referring ophthalmologists, who returned questionnaires.

The period of follow up was measured from the date of the first treatment to the date of the latest known status or, if the patient was dead, to the date when the database was closed, which was the 25 February 1991. The follow up varied from 7 days to 18 years 11 months, with a median of 28 months. Eleven patients were followed up for less than 1 month.

Patients with postoperative visual acuity of $6 / 12$ or better were categorised as having 'good vision.' Enucleated cases and those with vision of hand movements or worse were categorised as having 'severe visual loss.' Patients with visual acuity between $6 / 18$ and counting fingers were categorised as having 'moderate vision.'

The time to severe visual loss was measured from the date of the local resection to the date when the loss of vision was first reported; this was because such an event was likely to be recognised without significant delay. The time during which patients had good vision was measured from the date of the operation to the last date at which vision of $6 / 12$ or better was recorded; this was because patients with moderate visual loss may not have presented before their next routine appointment.

In relation to patients losing vision, $\mathrm{p}$ values for the univariate comparison of time to events (that is, loss of 'good vision' or 'severe visual loss') between different groups were derived by fitting Cox's proportional hazards model ${ }^{22}$ to the data; estimates of relative event rates were obtained in the same way. A forward stepwise procedure ( $p$ to enter $=p$ to remove $=0.05$ ) was 
Table 1 Summary of patient and tumour data and univariate analysis of retention of good vision (that is, $6 / 12$ or better)

\begin{tabular}{|c|c|c|c|c|c|c|}
\hline \multirow[b]{2}{*}{ Variable } & \multirow[b]{2}{*}{ Categories } & \multirow{2}{*}{$\begin{array}{l}\text { No of } \\
\text { patients }\end{array}$} & \multirow{2}{*}{$\begin{array}{l}\text { Relative rate of } \\
\text { loss of good vision }\end{array}$} & \multicolumn{2}{|c|}{$\begin{array}{l}95 \% \text { Confidence interval for } \\
\text { relative rate of visual loss }\end{array}$} & \multirow[b]{2}{*}{$p$ Value } \\
\hline & & & & Lower limit & Upper limit & \\
\hline Sex & $\begin{array}{l}\text { Female } \\
\text { Male }\end{array}$ & $\begin{array}{l}69 \\
94\end{array}$ & $\begin{array}{l}1 \\
1 \cdot 19\end{array}$ & $\overline{0} \cdot 83$ & $\overline{1} \cdot 72$ & $0 \cdot 328$ \\
\hline $\begin{array}{l}\text { Age at } \\
\text { diagnosis } \\
\text { (years) }\end{array}$ & $\begin{array}{l}<40 \\
40-60 \\
>60\end{array}$ & $\begin{array}{l}36 \\
87 \\
40\end{array}$ & $\begin{array}{l}1 \\
1 \cdot 10 \\
1 \cdot 49\end{array}$ & $\begin{array}{l}0 \\
0 \cdot 32 \\
0 \cdot 90\end{array}$ & $\begin{array}{l}1.12 \\
1 \cdot 51 \\
2 \cdot 48\end{array}$ & 0.098 \\
\hline Eye & $\begin{array}{l}\text { Left } \\
\text { Right }\end{array}$ & $\begin{array}{l}95 \\
68\end{array}$ & 1 & $\overline{0} \cdot 68$ & $\overline{1} \cdot 39$ & 0.856 \\
\hline $\begin{array}{l}\text { Initial } \\
\text { vision }\end{array}$ & $\begin{array}{l}6 / 6-6 / 9 \\
6 / 12-6 / 36 \\
6 / 60-C F\end{array}$ & $\begin{array}{l}94 \\
47 \\
22\end{array}$ & $\begin{array}{l}1 \\
1 \cdot 54 \\
1 \cdot 80\end{array}$ & $\begin{array}{l}- \\
1 \cdot 03 \\
1 \cdot 10\end{array}$ & $\begin{array}{l}- \\
2 \cdot 30 \\
2 \cdot 97\end{array}$ & 0.023 \\
\hline $\begin{array}{l}\text { Anterior } \\
\text { margin }\end{array}$ & $\begin{array}{l}\text { Behind equator } \\
\text { Equator to ora } \\
\text { Anterior to ora }\end{array}$ & $\begin{array}{r}17 \\
115 \\
31\end{array}$ & $\begin{array}{l}1 \\
0 \cdot 63 \\
0 \cdot 60\end{array}$ & $\begin{array}{l}\overline{0} \\
0 \cdot 37 \\
0 \cdot 32\end{array}$ & $\begin{array}{l}- \\
1 \cdot 08 \\
1 \cdot 16\end{array}$ & $0 \cdot 221$ \\
\hline $\begin{array}{l}\text { Posterior } \\
\text { margin }\end{array}$ & $\begin{array}{l}>1 \text { DD from disc or fovea } \\
\leqslant 1 \text { DD from disc or fovea }\end{array}$ & $\begin{array}{r}125 \\
38\end{array}$ & $\begin{array}{l}1 \\
1 \cdot 46\end{array}$ & $\overline{0} \cdot 98$ & - & 0.063 \\
\hline $\begin{array}{l}\text { Coronal } \\
\text { location }\end{array}$ & $\begin{array}{l}\text { Nasal } \\
\text { Midline and temporal }\end{array}$ & $\begin{array}{l}67 \\
96\end{array}$ & 1.67 & $\overline{1} \cdot 14$ & $2 \cdot 45$ & 0.008 \\
\hline $\begin{array}{l}\text { Sagittal } \\
\text { location }\end{array}$ & $\begin{array}{l}\text { Superior } \\
\text { Horizontal } \\
\text { Inferior }\end{array}$ & $\begin{array}{l}68 \\
33 \\
62\end{array}$ & $\begin{array}{l}1 \\
0 \cdot 96 \\
0 \cdot 84\end{array}$ & $\begin{array}{l}0.601 \\
0.56\end{array}$ & $\begin{array}{l}\overline{1} \cdot 54 \\
1 \cdot 26\end{array}$ & 0.696 \\
\hline $\begin{array}{l}\text { Largest } \\
\text { ultrasound } \\
\text { diameter }(\mathrm{mm})\end{array}$ & $\begin{array}{l}<11 \\
11-15 \\
>15\end{array}$ & $\begin{array}{l}34 \\
92 \\
14\end{array}$ & $\begin{array}{l}1 \\
1 \cdot 26 \\
1 \cdot 62\end{array}$ & $\begin{array}{l}\overline{0} \\
0 \cdot 78 \\
0 \cdot 80\end{array}$ & $\begin{array}{l}- \\
2 \cdot 04 \\
3 \cdot 28\end{array}$ & 0.388 \\
\hline $\begin{array}{l}\text { Ultrasound } \\
\text { height }(\mathrm{mm})\end{array}$ & $\begin{array}{l}\leqslant 8 \\
>8\end{array}$ & $\begin{array}{l}87 \\
37\end{array}$ & $1 \cdot 00$ & 0.63 & 1.59 & 0.991 \\
\hline $\begin{array}{l}\text { Largest } \\
\text { pathological } \\
\text { diameter } \neq(\mathrm{mm})\end{array}$ & $\begin{array}{l}<11 \\
11-15 \\
>15\end{array}$ & $\begin{array}{r}25 \\
105 \\
29\end{array}$ & $\begin{array}{l}1 \\
0 \cdot 81 \\
0 \cdot 85\end{array}$ & $\begin{array}{l}- \\
0 \cdot 50 \\
0 \cdot 46\end{array}$ & $\begin{array}{l}- \\
1 \cdot 33 \\
1.57\end{array}$ & 0.715 \\
\hline $\begin{array}{l}\text { Pathological } \\
\text { height } \oint(\mathrm{mm})\end{array}$ & $\begin{array}{l}<5 \\
5-8 \\
>8\end{array}$ & $\begin{array}{l}17 \\
90 \\
51\end{array}$ & $\begin{array}{l}1 \\
0 \cdot 80 \\
0 \cdot 81\end{array}$ & $\begin{array}{l}\overline{0} \\
0 \cdot 45 \\
0 \cdot 44\end{array}$ & $\begin{array}{l}1.43 \\
1.50\end{array}$ & 0.749 \\
\hline Cell type & $\begin{array}{l}\text { Spindle } \\
\text { Mixed/epithelioid }\end{array}$ & $\begin{array}{l}94 \\
69\end{array}$ & $1 \cdot 18$ & $\overline{0} \cdot 23$ & $1 \cdot 68$ & 0.367 \\
\hline $\begin{array}{l}\text { Ocular } \\
\text { decompression }\end{array}$ & $\begin{array}{l}\text { No } \\
\text { Yes }\end{array}$ & $\begin{array}{r}60 \\
103\end{array}$ & $1 \cdot 20$ & $\overline{0} \cdot 82$ & $-7 \cdot 76$ & 0.341 \\
\hline Clearance & $\begin{array}{l}\text { Adequate } \\
\text { Uncertain } \\
\text { Inadequate }\end{array}$ & $\begin{array}{l}46 \\
20 \\
97\end{array}$ & $\begin{array}{l}1 \\
0.92 \\
1.00\end{array}$ & $\begin{array}{l}\overline{0} \\
0.49 \\
0.66\end{array}$ & $\begin{array}{l}- \\
1 \cdot 71 \\
1 \cdot 50\end{array}$ & 0.958 \\
\hline
\end{tabular}

(Results not available for $23^{\star}, 39+, 4 \ddagger$ and $5 \$$ patients.)

used in conjunction with Cox's proportional hazards model to identify those factors influencing event rates most profoundly. Kaplan-Meier estimates ${ }^{23}$ were used to draw survival curves of time to events. Transient visual loss was disregarded.

Patients with melanoma entirely within the choroid were included in this study in addition to those patients with a choroidal tumour and minimal ciliary body involvement (that is, not requiring iridectomy). Patients were excluded from the construction of the models for predicting visual outcome if the operation was abandoned in favour of another form of conservative therapy or enucleation, or if the preoperative visual acuity was worse than counting fingers. The outcome in these patients is nevertheless reported in the next section.

\section{Results}

PATIENT CHARACTERISTICS

A total of 163 patients were included in the analysis (Table 1). The mean age at the time of local resection was 50 years (SD 13.3; range 19-78). A small minority of patients were known to suffer from systemic disease, either concurrently or previously, which included systemic hypertension (two), pulmonary disease (three), diabetes mellitus (two), dysthyroidism (three), epilepsy (one), deep vein thrombosis (one), and cardiac arrhythmia requiring a pacemaker (one). The vision in the fellow eye was $6 / 12$ or better in $90 \%$ of patients; however, 11 fellow eyes were amblyopic, four were glaucomatous, three had marked lattice degeneration, and one had received plaque radiotherapy for a choroidal melanoma. The vision in the operated eye was $6 / 12$ or better in $58 \%$ of eyes at the time of surgery. Reduced preoperative visual acuity was usually due to secondary retinal detachment or macular involvement by the tumour. Other ocular abnormalities in the operated eye included cataract (two), uveitis (two), amblyopia (one), and atrophic macular degeneration (one).

Seventeen tumours $(10 \%)$ were located entirely behind the equator of the eye. The posterior margin of the tumour extended to within $1 \mathrm{DD}(1.5 \mathrm{~mm})$ of the optic disc or fovea in

Table 2 Multivariate analysis of predictive factors for retention of good vision

\begin{tabular}{|c|c|c|c|c|c|c|}
\hline \multirow[b]{2}{*}{ Variable } & \multirow[b]{2}{*}{ Categories } & \multirow{2}{*}{$\begin{array}{l}\text { No of } \\
\text { patients }\end{array}$} & \multirow{2}{*}{$\begin{array}{l}\text { Relative rate of } \\
\text { loss of good vision }\end{array}$} & \multicolumn{2}{|c|}{$\begin{array}{l}95 \% \text { Confidence interval for } \\
\text { relative rate of visual loss }\end{array}$} & \multirow[b]{2}{*}{$p$ Value } \\
\hline & & & & Lower limit & Upper limit & \\
\hline $\begin{array}{l}\text { Coronal } \\
\text { location }\end{array}$ & $\begin{array}{l}\text { Nasal } \\
\text { Midline or temporal }\end{array}$ & $\begin{array}{l}67 \\
96\end{array}$ & 1.87 & $\overline{1} \cdot 26$ & $\overline{2} \cdot 79$ & $0 \cdot 002$ \\
\hline $\begin{array}{c}\text { Posterior } \\
\text { margin }\end{array}$ & $\begin{array}{l}\text { 1 DD from disc or fovea } \\
\leqslant 1 \text { DD from disc or fovea }\end{array}$ & $\begin{array}{r}90 \\
125 \\
38\end{array}$ & $\begin{array}{l}1 \cdot 87 \\
1 \\
1 \cdot 72\end{array}$ & $\begin{array}{l}1 \cdot 26 \\
\overline{1} \cdot 14\end{array}$ & $\begin{array}{l}2 \cdot 79 \\
2 \cdot 61\end{array}$ & 0.010 \\
\hline
\end{tabular}




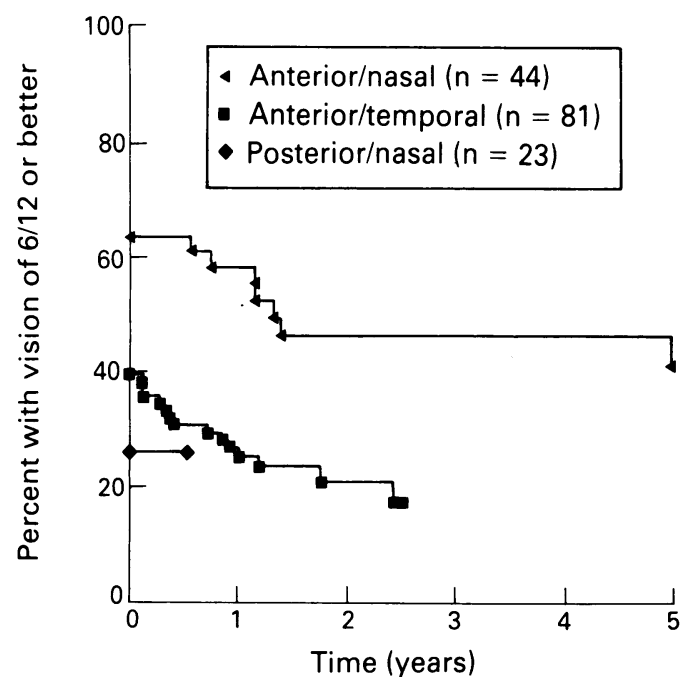

Figure 2 Kaplan-Meier curves showing the percentage of patients with vision of 6/12 or better according to coronal tumour location and posterior tumour extension. No patients with posterior/temporal tumours $(n=15)$ achieved a vision of $6 / 12$ or better.

38 eyes (23\%), with involvement the fovea in two patients (1\%) and the margin of the optic disc in 10 patients $(6 \%)$. The mean largest tumour diameter was 13.3 (SD $3.2 \mathrm{~mm}$ ) on pathology, with the tumour height averaging $7 \cdot 4$ (SD $2 \cdot 5$ $\mathrm{mm})$. Many tumours were adherent to the retina but definite retinal invasion and perforation were recorded in 21 eyes (13\%). Two tumours showed transscleral extension requiring full thickness scleral resection. A total of 69 tumours $(42 \%)$ were classified as being of mixed or epithelioid cell type.

\section{PREDICTIVE FACTORS FOR RETENTION OF GOOD} VISION

Univariate analysis showed that the only significant preoperative variables predicting the retention of vision of $6 / 12$ or better were (i) nasal tumour location $(\mathrm{p}=0.008)$ and (ii) good preoperative vision $(\mathrm{p}=0.023)$ (Table 1$)$. A forward stepwise selection procedure was carried out using age, sex, eye, preoperative vision, coronal and sagittal tumour locations, and location of anterior and posterior tumour margins as candidates for inclusion in the multivariate analysis; ultrasonographic measurements were not included because data were not available from a large number of patients and because this variable was not shown to be significant on univariate analysis. The results of a stepwise selection procedure indicated in a multivariate setting that the only preoperative variables that were statistically significant were (i) nasal tumour location $(p=0.002)$ and (ii) tumour margin more than 1 DD from the disc, fovea, or both $(p=0.010)$ (Table 2). Consideration of factors available intraoperatively and postoperatively (that is, ocular decompression, pathological measurements of tumour diameter and height, cell type, and surgical clearance) did not suggest that these provided any useful further information for predicting good vision over and above those factors already identified. The patients were categorised according to the number of risk factors present: (i) nasal tumours not extending within $1 \mathrm{DD}$ of the optic disc or fovea (44) had no risk factors; (ii) midline and temporal tumours not extending posteriorly (81) and nasal tumours

Table 3 Univariate analysis of risk of severe visual loss (that is, hand movements or worse)

\begin{tabular}{|c|c|c|c|c|c|c|}
\hline \multirow[b]{2}{*}{ Variable } & \multirow[b]{2}{*}{ Categories } & \multirow{2}{*}{$\begin{array}{l}\text { No of } \\
\text { patients }\end{array}$} & \multirow{2}{*}{$\begin{array}{l}\text { Relative rate of } \\
\text {, severe visual loss }\end{array}$} & \multicolumn{2}{|c|}{$\begin{array}{l}95 \% \text { Confidence interval for } \\
\text { relative rate of visual loss }\end{array}$} & \multirow[b]{2}{*}{$p$ Value } \\
\hline & & & & Lower limit & Upper limit & \\
\hline \multirow[t]{2}{*}{ Sex } & Female & 69 & 1 & - & - & \multirow{2}{*}{0.018} \\
\hline & Male & 94 & $2 \cdot 23$ & $1 \cdot 12$ & $4 \cdot 43$ & \\
\hline \multirow{2}{*}{$\begin{array}{l}\text { Age at } \\
\text { diagnosis } \\
\text { (years) }\end{array}$} & $<40$ & 36 & 1 & - & - & \multirow[t]{2}{*}{0.263} \\
\hline & $\begin{array}{l}40-60 \\
>60\end{array}$ & $\begin{array}{l}87 \\
40\end{array}$ & $\begin{array}{l}2.05 \\
1.74\end{array}$ & $\begin{array}{l}0.85 \\
0.62\end{array}$ & $\begin{array}{l}4 \cdot 96 \\
4 \cdot 89\end{array}$ & \\
\hline \multirow[t]{2}{*}{ Eye } & Left & 95 & 1 & - & - & \multirow[t]{2}{*}{$0 \cdot 300$} \\
\hline & Right & 68 & 1.39 & 0.74 & $2 \cdot 61$ & \\
\hline \multirow{2}{*}{$\begin{array}{l}\text { Initial } \\
\text { vision }\end{array}$} & $6 / 6-6 / 9$ & 94 & 1 & - & - & \multirow[t]{2}{*}{0.398} \\
\hline & $\begin{array}{l}6 / 12-6 / 36 \\
6 / 60-C F\end{array}$ & $\begin{array}{l}47 \\
22\end{array}$ & $\begin{array}{l}1 \cdot 26 \\
1.68\end{array}$ & $\begin{array}{l}1 \cdot 60 \\
1 \cdot 28\end{array}$ & $\begin{array}{l}2.53 \\
3.61\end{array}$ & \\
\hline \multirow{3}{*}{$\begin{array}{l}\text { Anterior } \\
\text { margin }\end{array}$} & Behind equator & 17 & 1 & - & - & \multirow{3}{*}{0.418} \\
\hline & Equator to ora & 115 & 0.58 & $0 \cdot 26$ & $1 \cdot 33$ & \\
\hline & Anterior to ora & 31 & 0.59 & $0 \cdot 21$ & $1 \cdot 68$ & \\
\hline \multirow{2}{*}{$\begin{array}{l}\text { Posterior } \\
\text { margin }\end{array}$} & >1 DD from disc or fovea & 125 & 1 & - & - & \multirow[t]{2}{*}{0.002} \\
\hline & $\leqslant 1$ DD from disc or fovea & 38 & $2 \cdot 49$ & $1 \cdot 36$ & $4 \cdot 57$ & \\
\hline \multirow{2}{*}{$\begin{array}{l}\text { Coronal } \\
\text { location }\end{array}$} & Nasal & 67 & 1 & - & - & \multirow{2}{*}{$0 \cdot 324$} \\
\hline & Midline and temporal & 96 & $1 \cdot 37$ & $0 \cdot 73$ & $2 \cdot 57$ & \\
\hline \multirow{2}{*}{$\begin{array}{l}\text { Sagittal } \\
\text { location }\end{array}$} & Superior & 68 & 1 & - & - & \multirow{3}{*}{$0 \cdot 153$} \\
\hline & $\begin{array}{l}\text { Horizontal } \\
\text { Inferior }\end{array}$ & $\begin{array}{l}33 \\
62\end{array}$ & 0.97 & $0 \cdot 46$ & $2 \cdot 07$ & \\
\hline \multirow{3}{*}{$\begin{array}{l}\text { Largest } \\
\text { ultrasound } \\
\text { diameter }^{\star}(\mathrm{mm})\end{array}$} & $<11$ & $\begin{array}{l}62 \\
34\end{array}$ & $\begin{array}{l}0.52 \\
1\end{array}$ & 0.25 & $1 \cdot 05$ & \\
\hline & $11-15$ & 92 & 0.74 & $0 \cdot 32$ & - & \multirow{2}{*}{0.771} \\
\hline & $>15$ & 14 & 0.85 & $0 \cdot 18$ & $\begin{array}{l}1 \cdot 70 \\
4 \cdot 02\end{array}$ & \\
\hline \multirow{3}{*}{$\begin{array}{l}\text { Ultrasound } \\
\text { height }+(\mathrm{mm})\end{array}$} & $<5$ & 6 & 1 & - & - & \multirow{3}{*}{$0 \cdot 805$} \\
\hline & $5-8$ & 81 & 1.43 & $0 \cdot 19$ & $10 \cdot 73$ & \\
\hline & $>8$ & 37 & $1 \cdot 76$ & $0 \cdot 22$ & 13.67 & \\
\hline \multirow{4}{*}{$\begin{array}{l}\text { Largest } \\
\text { pathological } \\
\text { diameter } \neq(\mathrm{mm}) \\
\text { Pathological }\end{array}$} & $<11$ & 25 & 1 & - & - & \multirow[t]{3}{*}{$0 \cdot 126$} \\
\hline & $11-15$ & 105 & $0 \cdot 50$ & $0 \cdot 22$ & $1 \cdot 14$ & \\
\hline & $>15$ & 29 & 0.91 & $0 \cdot 37$ & $2 \cdot 27$ & \\
\hline & $<5$ & 17 & 1 & - & - & 0.682 \\
\hline height $§(\mathrm{~mm})$ & $\begin{array}{l}5-8 \\
>8\end{array}$ & $\begin{array}{l}90 \\
51\end{array}$ & $\begin{array}{l}1.26 \\
1.58\end{array}$ & $\begin{array}{l}0.38 \\
0.46\end{array}$ & $\begin{array}{l}4 \cdot 20 \\
5 \cdot 47\end{array}$ & \\
\hline Cell type & Spindle & 94 & 1 & $\begin{array}{l}0.40 \\
-\end{array}$ & - & $0 \cdot 321$ \\
\hline & Mixed/epithelioid & 69 & $1 \cdot 37$ & $0 \cdot 74$ & $2 \cdot 54$ & \\
\hline Ocular & No & 60 & 1 & - & - & $0 \cdot 327$ \\
\hline decompression & Yes & 103 & $1 \cdot 41$ & $0 \cdot 70$ & $2 \cdot 82$ & \\
\hline Clearance & Adequate & 46 & 1 & - & - & 0.685 \\
\hline & $\begin{array}{l}\text { Uncertain } \\
\text { Inadequate }\end{array}$ & $\begin{array}{l}20 \\
97\end{array}$ & $\begin{array}{l}1.49 \\
1.37\end{array}$ & $\begin{array}{l}0.46 \\
0.64\end{array}$ & 4.88 & \\
\hline
\end{tabular}

(Results not available for $23^{\star}, 39 \dagger, 4 \ddagger$ and $5 \$$ patients.) 
Table 4 Multivariate analysis of predictive factors for severe visual loss

\begin{tabular}{|c|c|c|c|c|c|c|}
\hline \multirow[b]{2}{*}{ Variable } & \multirow[b]{2}{*}{ Categories } & \multirow{2}{*}{$\begin{array}{l}\text { No of } \\
\text { patients }\end{array}$} & \multirow{2}{*}{$\begin{array}{l}\text { Relative rate of } \\
\text { severe visual loss }\end{array}$} & \multicolumn{2}{|c|}{$\begin{array}{l}95 \% \text { Confidence interval for } \\
\text { relative rate of visual loss }\end{array}$} & \multirow[b]{2}{*}{ p Value } \\
\hline & & & & Lower limit & Upper limit & \\
\hline $\begin{array}{l}\text { Posterior } \\
\text { margin } \\
\text { Sex }\end{array}$ & $\begin{array}{l}>1 \text { DD from disc or fovea } \\
\text { 1 DD from disc or fovea } \\
\text { Female } \\
\text { Male }\end{array}$ & $\begin{array}{r}125 \\
38 \\
69 \\
94\end{array}$ & $\begin{array}{l}1 \\
2 \cdot 26 \\
1 \\
2 \cdot 00\end{array}$ & $\begin{array}{l}\overline{1} \cdot 23 \\
\overline{1} \cdot 00\end{array}$ & $\begin{array}{l}\overline{4} \cdot 17 \\
\overline{4} \cdot 00\end{array}$ & $\begin{array}{l}0.009 \\
0.050\end{array}$ \\
\hline
\end{tabular}

with posterior extension (23) had one risk factor; and (iii) midline and temporal tumours extending within $1 \mathrm{DD}$ of disc or fovea (15) had two risk factors. Figure 2 shows the Kaplan-Meier survival curves which give an indication of the proportion of patients in each category with vision of $6 / 12$ or better at various times after the operation.

\section{RISK FACTORS FOR SEVERE LOSS OF VISION}

Univariate Cox regression analysis showed that the only preoperative variables that were statistically significant risk factors for severe loss of vision were (i) posterior extension of the tumour $(\mathrm{p}=0.002)$ and (ii) male sex $(\mathrm{p}=0.018)$ (Table 3). A forward stepwise selection procedure was carried out using the same variables as above. This indicated that in a multivariate setting severe visual loss was related to (i) extension of the tumour to within $1 \mathrm{DD}$ from the disc or fovea $(p=0.009)$, and (ii) male sex $(p=0.050)$ (Table 4). As with the prediction of good visual acuity, consideration of ocular decompression, pathological measurements of tumour diameter and height, cell type, and clearance did not change the outcome of the stepwise selection procedure.

Table 5 Visual acuity after local resection according to posterior extent and coronal location of the tumour. The results at each time are given as a percentage of the total number of assessable patients followed up to that time or longer. The figures in parenthesis are the number of patients who were not examined at the specified time postoperatively

\begin{tabular}{|c|c|c|c|c|c|c|}
\hline & \multicolumn{6}{|c|}{ Time after local resection } \\
\hline & 6 months & 1 year & 2 years & 3 years & 4 years & 5 years \\
\hline \multicolumn{7}{|c|}{ (i) Nasal tumours without posterior extention } \\
\hline & & & 21 & 19 & 16 & 13 \\
\hline $\begin{array}{l}\text { Missing data } \\
6 / 6-6 / 12\end{array}$ & $(0)$ & (1) & $\left(\begin{array}{c}(0) \\
48\end{array}\right.$ & (0) & $(2)$ & $(0)$ \\
\hline $6 / 18-6 / 36$ & 24 & 21 & $\begin{array}{l}40 \\
19\end{array}$ & 26 & 25 & $\begin{array}{l}54 \\
15\end{array}$ \\
\hline 6/60-CF & 26 & 14 & 19 & 5 & 0 & 8 \\
\hline HM-NPL & & 7 & 10 & 21 & 19 & 23 \\
\hline & 3 & 0 & 5 & 5 & 6 & 0 \\
\hline \multicolumn{7}{|c|}{ (ii) Temporal tumours without posterior extension } \\
\hline${ }_{\text {Missing data }}^{\mathrm{n}}$ & 68 & & 33 & 29 & 23 & 16 \\
\hline $\begin{array}{l}\text { Missing data } \\
6 / 6-6 / 12\end{array}$ & (2) & 25 & $\begin{array}{l}(5) \\
18\end{array}$ & $(2)$ & (1) & (1) \\
\hline $6 / 18-6 / 36$ & 18 & 18 & 12 & $\begin{array}{l}14 \\
14\end{array}$ & $\begin{array}{r}17 \\
0\end{array}$ & $\begin{array}{l}6 \\
0\end{array}$ \\
\hline 6/60-CF & 34 & 39 & 33 & 28 & 43 & 56 \\
\hline HM-NPL & 12 & 7 & 9 & 14 & 13 & 13 \\
\hline EN & & 11 & 27 & 31 & 26 & 25 \\
\hline \multicolumn{7}{|c|}{ (iii) Nasal tumours extending to within one disc diameter of the disc or fovea } \\
\hline & & 13 & & $\begin{array}{c}9 \\
(0)\end{array}$ & $\begin{array}{l}7 \\
(0)\end{array}$ & 4 \\
\hline $\begin{array}{l}\text { Missing data } \\
6 / 6-6 / 12\end{array}$ & (0) & 23 & 33 & 33 & 29 & $\begin{array}{l}\text { (0) } \\
50\end{array}$ \\
\hline $6 / 18-6 / 36$ & 13 & 15 & 11 & 11 & 14 & 0 \\
\hline 6/60-CF & 38 & 38 & 33 & 33 & 29 & 25 \\
\hline HM-NPL & 25 & 15 & 11 & 0 & 14 & 0 \\
\hline EN & & & 11 & 22 & 14 & 25 \\
\hline \multicolumn{7}{|c|}{ (iv) Temporal tumours extending to within one disc diameter of the disc or fovea } \\
\hline${ }_{\text {Missing data }}^{\mathrm{n}}$ & & & & & & \\
\hline $\begin{array}{l}\text { Missing data } \\
6 / 6-6 / 12\end{array}$ & $\begin{array}{c}(0) \\
0\end{array}$ & (0) & $\begin{array}{c}(0) \\
0\end{array}$ & $\begin{array}{c}(0) \\
0\end{array}$ & $\begin{array}{c}(0) \\
0\end{array}$ & $\begin{array}{l}(0) \\
0\end{array}$ \\
\hline 6/18-6/36 & 14 & 17 & 18 & 13 & 0 & 0 \\
\hline 6/60-CF & 50 & 33 & 36 & 25 & 50 & 40 \\
\hline HM-NPL & 29 & 42 & $\begin{array}{r}9 \\
36\end{array}$ & $\begin{array}{r}0 \\
63\end{array}$ & $\begin{array}{r}0 \\
50\end{array}$ & 0 \\
\hline & & & 36 & 63 & 50 & 60 \\
\hline
\end{tabular}

$\mathrm{CF}=$ counting fingers, $\mathrm{HM}=$ hand movements, $\mathrm{NPL}=$ no perception of light, $\mathrm{EN}=$ enucleated.
The patients were categorised according to the number of risk factors present: (i) women without posterior tumour extension had no risk factors (58); (ii) women with posterior tumour extension (11) and men without posterior tumour extension (67) had one risk factor; and (iii) men with posterior tumour extension (27) had two risk factors. Figure 3 shows the time to severe visual loss according to posterior tumour extension and sex. The best results occurred in women without posterior extension; approximately $20 \%$ of patients in this group had severe visual loss at 4 years, compared with $35 \%$ of men without posterior tumour extension and $55 \%$ of men with posterior tumour extension.

\section{VISUAL RESULTS}

Table 5 summarises the postoperative visual acuity at 6 months, and then at yearly intervals for up to 5 years according to whether or not the posterior tumour margin extended to within 1 DD of the optic disc or fovea and according to whether or not the tumour was located nasally. One year postoperatively, all 28 patients with nasal tumours not having posterior extension retained the eye, $93 \%$ having vision of counting fingers or better and $57 \%$ having vision of $6 / 12$ or better. With temporal tumours not having posterior extension, $89 \%$ of 56 patients still had the eye at 1 year, $82 \%$ having vision of counting fingers or better, and $25 \%$ retaining vision of $6 / 12$ or better. With regards to tumours extending to within $1 \mathrm{DD}$ of the disc, fovea, or both, the results were again better when the tumour was situated nasally than when it was located temporally. In 13 patients with a nasal tumour, 12

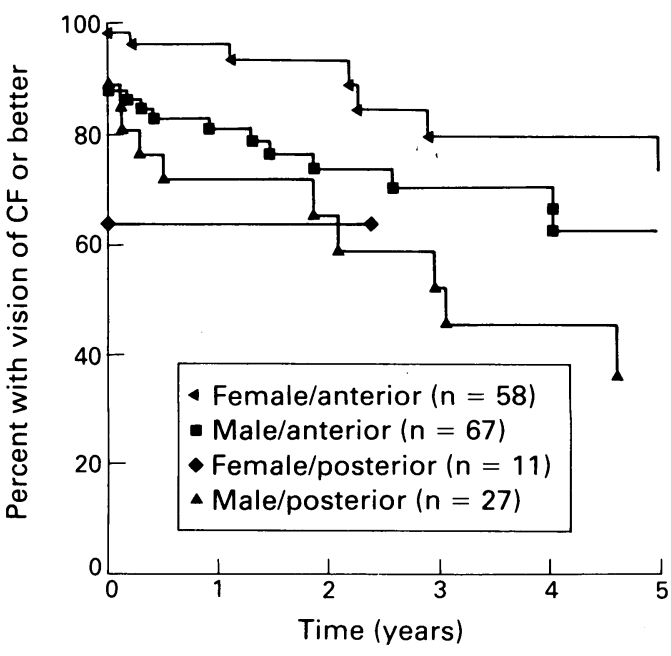

Figure 3 Kaplan-Meier curves showing the percentage of patients with vision of counting fingers $(C F)$ or better according to sex and posterior tumour extension. 
retained the eye at 1 year with 10 having vision of counting fingers or better and three having vision of $6 / 12$ or better. In contrast, none of the 12 patients with a temporal tumour and posterior extension retained vision of $6 / 12$ or better, although 11 eyes were saved, with six having vision of counting fingers or better.

\section{CAUSES OF SEVERE VISUAL LOSS}

Residual tumour diagnosed clinically or after enucleation occurred in 52 out of 163 patients (32\%) but contributed to severe visual loss in only $17(10 \%)$ patients. Three patients with clinical residual tumour were unable to return for plaque radiotherapy or other conservative treatment and underwent enucleation by their ophthalmologist. Five patients had enucleation because of extraocular tumour extension, which was associated with intraocular metastasis (one), unrecognised intraocular recurrence (three), or unsuccessful photocoagulation (one). In five patients, the recurrent tumour was situated at the optic disc so that photocoagulation was either not possible or unsuccessful. One patient developed a retinal detachment after plaque radiotherapy of residual disease and in three patients retinal detachment followed photocoagulation for residual tumour.

Retinal detachment occurred in 49 out of 163 patients $(30 \%)$ and was the main cause of visual loss in 20 patients (12\%). In two patients, the retinal detachment was associated with a disinsertion of the retina at the ora serrata. In 13 patients, the retinal damage occurred intraoperatively due to adhesion of the tumour to the retina (seven), retinal prolapse through the scleral opening (four), or complicated tumour excision due to separation of the tumour from the sclera (two). In one patient, the tumour had perforated the retina. One patient is believed to have developed retinal atrophy over the coloboma, with eventual hole formation and detachment. In one patient, the retinal damage occurred during vitrectomy for vitreous haemorrhage following local resection. Retinal detachment surgery was considered inappropriate in a number of cases because of advanced proliferative vitreoretinopathy or suspected residual tumour. In those cases operated on, anatomical success was achieved in about half.

The causes of macular damage were not readily categorised, especially if multifactorial; they included preoperative and postoperative retinal detachment, tumour invasion, submacular choroidal resection, radiation retinopathy, and cystoid macular oedema. One patient developed a macular epiretinal membrane, which was successfully treated surgically with a final vision of $6 / 18$. Four patients developed disciform lesions arising from surgical colobomas extending to the macula.

Cataract of any severity was recorded in 24 eyes $(15 \%)$ and was usually associated with other complications, such as retinal detachment (nine) or recurrent tumour (five), or both complications (three). Six patients underwent lens extraction, with two regaining vision of $6 / 36$ or better. Vitreous haemorrhage severe enough to prevent the optic disc from being seen occurred in 30 patients and usually resolved spontaneously, especially if pars plana vitrectomy had been performed during the local resection. Miscellaneous other complications included uveitis (two), bullous keratopathy (one), which occurred after a complicated lens extraction, phthisis (one), glaucoma (one), optic atrophy after excision of a juxtapapillary tumour (one), and diplopia (15), which resolved spontaneously except for two patients who required extraocular muscle surgery. At the close of the study, 20 patients $(12 \%)$ had died of metastatic disease; another two patients had died of other causes (bronchopneumonia and bronchial carcinoma respectively) and two patients were alive with known metastases.

There were three patients categorised as having severe visual loss whose vision subsequently improved after the close of the study. In one patient with a disciform macular lesion caused by choroidal new vessels arising from the margins of the coloboma, the vision later improved to counting fingers eccentrically. Two patients had vitreous haemorrhage, which subsequently resolved after the completion of the study so that the vision improved to counting fingers or better.

\section{EXCLUDED PATIENTS}

In 13 patients the local resection was abandoned in favour of photocoagulation (two); plaque radiotherapy (three); or enucleation (eight) because of (i) incomplete excision (one), retinal damage (two) or both (five); (ii) underestimation of the extent of the tumour preoperatively (two); (iii) excessive retinal bulging of the retina through the scleral window (one); and (iv) poor tolerance of the hypotensive anaesthesia (one), with the exact cause being unknown in one patient treated early in the study. Four of the five patients whose local resection was abandoned in favour of conservative therapy retained a visual acuity of counting fingers or better at the close of the study. Six patients, with preoperative visual acuity of hand movements or worse were excluded from the construction of the predictive model because the group was too small to allow such poor vision to be identified statistically as an adverse prognostic factor. All six patients retained the eye at the close of the study, with two having vision of counting fingers or better.

\section{Discussion}

This is the largest series of choroidal melanomas treated by local resection yet reported, both in terms of the number of patients and the length of follow up. Other studies have been much smaller. For the first time, the number of patients is sufficient to allow the identification of factors which are important in predicting visual outcome after surgical resection. These are coronal tumour location, distance between tumour and disc or fovea, and sex.

The prolonged duration of this study, which spanned almost 20 years, complicates the interpretation of the results because of the way in which the surgical procedures have changed with time. Furthermore, in the early years of the 
study, techniques such as ruthenium plaque radiotherapy, laser photocoagulation, and advanced vitreoretinal surgery were not yet available to us and when they were first applied, it took some time for optimal techniques to be developed. For these reasons, the results of this study presented in the figures and table are to some extent historical and do not necessarily represent the current potential of local resection.

\section{PREDICTIVE FACTORS}

It is not surprising that poor visual outcome was related to extension of the tumour to within $1 \mathrm{DD}$ of the disc or fovea. Such tumours were technically more difficult to resect and, as a result, incomplete excision and retinal damage were more common. Furthermore, with tumours extending close to disc, clinical residual disease after resection tended to be located near or at the optic disc so that further conservative treatment was difficult or impossible.

The proportion of patients retaining good vision was higher when the tumour was located nasally. There are several reasons for this finding. Because of the nasal location of the optic disc, the posterior margin of nasal tumours was located further anteriorly than that of midline and temporal tumours so that the operation was easier. The surgical resection was more straightforward with nasal tumours also because of the absence of oblique muscles and the lack of any hindrance by the bridge of the nose (because the surgeon usually sits diametrically opposite the tumour). Furthermore, because nasal tumours did not extend as close to the fovea as temporal tumours there was less risk of foveal damage.

The finding that male sex is a borderline predictor for severe visual loss could be due to chance or to some form of bias in the selection of treatment by the patients themselves, by the referring ophthalmologists, or by the clinical authors. It is also possible that men were more likely to have adverse factors that were not identified for inclusion in the multivariate analysis. In this respect, it is interesting that laser capsulotomy is more likely to be complicated by retinal detachment in men than in women (Cox proportional hazards model, $\mathrm{p}<0 \cdot 0001) .{ }^{24}$

Advanced patient age, large tumour size, inadequate tumour clearance, and epitheloid cellularity were not useful predictors of severe visual loss, although as previously shown they are relevant to survival. ${ }^{18}$ Initially, it was believed that local resection was contraindicated when the patient was more than 70 years old; however, it has recently become apparent that in elderly patients, less profound hypotension is required than in younger patients. Larger tumours tend to be easier to excise than small tumours because they are usually surrounded by subretinal fluid and are more strongly attached to sclera. There were many patients with apparently incomplete tumour excision on histopathological examination and no subsequent clinical evidence of residual tumour. This apparent discrepancy may be due to distortion of the specimen during pathological processing and to the effect of postoperative photocoagulation.

\section{COMPLICATIONS}

Retinal detachment was a serious complication, because it was difficult to treat and also because it interfered with the management of any clinical residual or recurrent tumour. Clinically evident residual or recurrent tumour was the second major complication, which occurred more commonly when the tumour extended far posteriorly. Conservative treatment of residual tumour was impossible or unsuccessful when the tumour was diffuse, or if it extended extraocularly or up to the optic disc. Retinal detachment and residual tumour after local resection are currently being investigated and will be reported separately.

\section{COMPARISON WITH OTHER STUDIES}

Comparison of the results of our choroidectomies with those reported by other workers is limited by differences in the selection criteria and in the presentation of data. Peyman and associates have reported the results of 37 eyewall resections for uveal melanoma, which were performed after photocoagulation and with the use of an eye basket. ${ }^{14}$ About $70 \%$ of eyes were saved, with $43 \%$ ultimately retaining vision of counting fingers or better but the tumours in that study were smaller and more anterior than in the present series. Augsburger and associates have compared the results of 30 surgical resections with a matched group of patients treated by cobalt plaque radiotherapy. ${ }^{15}$ Meaningful comparisons with the present study are not possible, however, because only a minority of their tumours were located entirely within the choroid and because the data relating to these tumours are incorporated with those of iridocyclectomies. Similar considerations also preclude comparison between our series and that of Shields and associates, who have merged the data of six lamellar sclerochoroidectomies with iridocyclectomies and included non-melanomatous tumours in their sample. ${ }^{16}$

Given the choice, the selection between local resection and plaque or charged particle radiotherapy depends on many factors, particularly the tumour's size and location. It would have been interesting to compare the results of the present study with visual outcome reported after radiotherapy, but this is not yet possible because of differences between studies in the categorisation of data. Local resection is our treatment of choice for choroidal tumours more than $5 \mathrm{~mm}$ in thickness, whereas radiotherapy is preferred for less bulky tumours, using a ruthenium plaque for anterior tumours and proton beam radiotherapy for tumours extending close to the optic disc or fovea. Nevertheless, prospective randomised trials would be desirable so as to enable more rational selection between these two forms of treatment in borderline cases.

The visual results of local resection of choroidal melanomas are encouraging, especially with tumours that do not extend close to the disc or fovea. The two main causes of severe visual loss are residual tumour and retinal detachment. It is likely that the results of local resection will improve in the future as these two complications are prevented and treated more effectively. 
Supported in parts by grants from the Scottish Home and Health Department, 150/799, Greater Glasgow Health Board, the Ross Foundation for the Prevention of Blindness (Scotland), and the Hayward Foundation.

The authors wish to thank all the ophthalmologists who have referred patients to the Ophthalmic Oncology Service and who have returned questionnaires. We also acknowledge the contribuhave returned questionnaires. We also acknowledge the contribu-
tion of Professor $W \mathbb{R}$ Lee, who performed the pathological tion of Professor W R Lee, who
examination of the resected tumours.

1 Lommatzsch PK, Kirsch IH. ${ }^{100} \mathrm{Ru} /{ }^{100} \mathrm{Rh}$ plaque radiotherapy for malignant melanomas of the choroid. With follow-up results more than 5 years. Doc Ophthalmol 1988; 68: 225-38.

2 Packer S, Stoller S, Lesser ML, Mandel FS, Finger PT. Long term results of iodine ${ }^{-125}$ irradiation of uveal melanoma. Ophthalmology 1992; 99: 767-74.

3 Gragoudas ES, Seddon JM, Egan K, Glynn R, Munzenrider J, Austin Seymour M, et al. Long-term results of proton beam
irradiated uveal melanomas. Ophthalmology 1987; 94: 349-53.

4 Linstadt D, Castro J, Char D, Decker M, Ahn D, Petti P, et al. Long-term results of helium ion irradiation of uveal

5 Foulds WS, Damato BE. Low-energy long-exposure laser therapy in the management of choroidal melanoma. Graefes therapy in the management of choroidal me

6 Schubert F. Operation eines leucosarkomas der choroidea mit erhaltung des auges dauer heilung. Wein Klin Wochenschr erhaltung des auge

7 Stallard HB. Partial choroidectomy. Brf Ophthalmol 1966; 50: 660-2.

8 Meyer Schwickerath G. Excision of malignant melanoma of the choroid. Mod Probl Ophthalmol 1974; 12: 562-6.

9 Foulds WS. The local excision of choroidal melanomata. Trans Ophthalmol Soc UK 1973; 93: 343-6.

10 Kara GB. Excision of uveal melanomas: a 15-year experience. Ophthalmology 1979; 86: 997-1023.

11 Billson FA. Microsurgery of choroidal melanoma - surgical techniques of local excision. Aust $\mathcal{F}$ Ophthalmol 1983; 11 21-7.
12 De Muynck M, Monteyne MC, Dralands L, Missotten L. Local excision of malignant melanomas from the choroid. Bull Soc Belge Ophtalmol 1986; 213: 19-26.

13 Peyman GA, Charles H. Internal eye wall resection in the management of uveal melanoma. Can $\mathcal{F}$ Ophthalmol 1988; 23: 218-23.

14 Peyman GA, Gremillion CM. Eye wall resection in the management of uveal neoplasms. $f_{p n} \mathcal{f}$ Ophthalmol 1989; 33: manage 71 .

15 Augsburger JJ, Lauritzen K, Gamel JW, DeBrakeleer DJ, Lowry JC, Eisenman R. Matched group study of surgical resection versus cobalt-60 plaque radiotherapy for primary choroidal or ciliary body melanoma. Ophthalmic Surg 1990; 21: 682-8.

16 Shields JA, Shields CL, Shah P, Sivalingam V. Partial lamellar sclerouvectomy for ciliary body and choroidal tumors. Ophthalmology 1991; 98: 971-83.

17 Foulds WS, Damato BE. Surgical resection of choroidal melanomas. In: Ryan SJ, Ogden TE, Schachat AP, eds. Retina. St Louis: Mosby 1989: 713-20.

18 Foulds WS, Damato BE, Burton RL. Local resection versus enucleation in the management of choroidal melanoma. Eye 1987; 1: 676-9.

19 Foulds WS, Damato BE. Alternatives to enucleation in the management of choroidal melanoma. Aust NZ $\mathcal{F}$ Ophthalmol 1986; 14: 19-27.

20 Damato BE, Foulds WS. Surgical resection of choroidal melanomas. In: Ryan SJ, Ogden TE, Schachat AP, eds. melanomas. In: Ryan SJ, Ogden TE, Schac

21 Todd JG, Colvin JR. Ophthalmic surgery. In: MacRae WR, Wildsmith JAW, eds. Induced hypotension. Amsterdam: Wildsmith JAW, eds.

22 Cox NH, Oakes D. Analysis of survival data. London: Chapman and Hall, 1984.

23 Armitage P, Berry G. Statistical methods in medical research. 2nd ed. Oxford: Blackwell, 1987

24 Javitt JC, Tielsch JM, Canner JK, Kolb MM, Sommer A, Steinberg EP. National outcomes of cataract extraction. Increased risk of retinal complications with Nd: YAG laser capsulotomy. Ophthalmology 1992; 29: 1487-98. 